\title{
Straw uses trade-off only after soil organic carbon steady-state
}

\author{
Agata Novara, ${ }^{1}$ Mauro Sarno, ${ }^{1}$ Paulo Pereira, ${ }^{2}$ Artemi Cerdà, ${ }^{3}$ Eric C. Brevik, ${ }^{4}$ \\ Luciano Gristina ${ }^{1}$ \\ ${ }^{1}$ Dipartimento di Scienze Agrarie, Alimentari e Forestali, University of Palermo, Palermo, Italy; \\ ${ }^{2}$ Environmental Management Centre, MykolasRomeris University, Vilnius, Lithuania; ${ }^{3}$ Soil Erosion and \\ Degradation Research Group, Department of Geography, University of Valencia, Valencia, Spain; \\ ${ }^{4}$ Department of Natural Sciences, Dickinson State University, Dickinson, ND, USA
}

\begin{abstract}
Soil organic matter (SOM) is the key for a healthy soil and a relevant property to achieve the sustainability on soil management. However, soils are still net exporters of organic matter. One example is the use of wheat straw residue for industrial and energy applications, which has gained attention in the last years. The offfarm use of this abundant and low cost resource should follow sustainability criteria to avoid soil degradation and SOM losses. Straw residue incorporation is recognized as a recommended management practice to control erosion and mitigate $\mathrm{CO}_{2}$ emissions by increasing SOM. The goal of this work was: i) to evaluate the steady-state carbon (C) level in relation to $\mathrm{C}$ input and estimate the minimum residue input needed to maintain this SOC level in a durum wheat-based cropping system in long-term experiment; and ii) estimate the potential availability of durum wheat straws for alternative use. Results showed that a $\mathrm{C}$ steady-state can be achieved after 3.4 years with an annual organic $C$ input of 4.5 $\mathrm{Mgha}^{-1}$. Only after reaching a steady-state, straws can be used for trade-off, leaving 1.03 $\mathrm{Mgha}^{-1} \mathrm{y}^{-1}$ of $\mathrm{C}$ input remain in the soil.
\end{abstract}

\section{Introduction}

The soil system is a key component of the Earth System as it controls the flow of matter and energy within the hydrological,

\footnotetext{
Correspondence: Luciano Gristina, Dipartimento di Scienze Agrarie, Alimentari e Forestali, University of Palermo, ed. 4, viale delle Scienze, 90128 Palermo, Italy.

E-mail: luciano.gristina@unipa.it
}

Key words: Carbon input maintain; Mediterranean durum wheat-based system; soil carbon sequestration; regional straw assessement.

Received for publication: 29 August 2017.

Revision received: 12 February 2018.

Accepted for publication: 13 February 2018.

(C) Copyright A. Novara et al., 2018

Licensee PAGEPress, Italy

Italian Journal of Agronomy 2018; 13:1101

doi:10.4081/ija.2018.1101

This article is distributed under the terms of the Creative Commons Attribution Noncommercial License (by-nc 4.0) which permits any noncommercial use, distribution, and reproduction in any medium, provided the original author(s) and source are credited. erosional, biological, ecological and geochemical cycles (Smith et al., 2015). Soil also contributes key resources, goods, and services to human kind, which makes soil a crucial factor in achieving sustainability of human societies. Human activities change the fate of the carbon cycle and can trigger degradation of the land (Chen et al., 2016; de Moraes Sá et al., 2015). Contemporaneously, a social interest to protect the soil system is increasing. Returning residues into the soil (straw, pruned branches, leaves) is a key strategy to help achieve this challenge (Lafond et al., 2009: Johnson et al., 2014; Cerdà et al., 2016). Straw return into the soil, in fact, has been suggested as a recommended management practice to increase soil organic carbon (SOC) stocks in agricultural lands leading to consequent mitigation of atmospheric $\mathrm{CO}_{2}$ emissions (Liu et al., 2014; Xia et al., 2014). As indicated by Lal (2005), the indiscriminate removal of crop residues can lead to a reduction in soil quality due to the loss of organic matter (Wilhelm et al., 2004), resulting in an overall decline of the soil structure (Samahadthai et al., 2010), water retention and altering the nutrient cycle (Lal, 2005). Straw incorporation as a sustainable management practice for SOC increase has been widely demonstrated by short and long-term experiments and by simulation models for predicting soil carbon (C) stock (Saffih-Hdadi and Mary, 2008; Dikgwatlhe et al., 2014; Bleuler et al., 2017; Farina et al., 2017).

Differences in the magnitude of SOC increase are attributable to many factors, including straw $\mathrm{C}$ input, $\mathrm{C} / \mathrm{N}$ ratio and soil condition (e.g. texture, temperature, and water content), nitrogen application, methods of incorporation, and tillage practices.In general, the increase of SOC stock is limited by the capacity of the soil to store additional C (C steady-state), and therefore no linear relationship between $\mathrm{C}$ residue input and $\mathrm{SOC}$ sequestration rate has been demonstrated in previous works (Garcia-Diaz et al., 2016; Novara et al., 2016). After reaching the C steady-state level, there is equilibrium between $\mathrm{C}$ input humification and $\mathrm{C}$ losses through mineralization and erosion. The amount of biomass residue that is needed to maintain a given SOC level is defined as $\mathrm{C}$ input maintain (Johnson et al., 2014). Assessing C input maintain is a critical need, considering that the removal of crop straw from soil has gained attention for alternative uses in the last few years (energy source or industrial processing) (Wamukonya and Jenkins, 1995; Qureshi et al., 2010; Scarlat et al., 2010).

The common management of the straw in the past was to bale and remove it from soils for use in livestock feed rations and as animal bedding, or marginally buried into the soil. Over the last 15-20 years, studies on the potential of lignocellulosic material for the production of biofuels, chemicals, and other by-products and the rising cost of petroleum (prior to 2016) resulted in a growing interest in the use of straw for energy production (Gray et al., 2006; Antoni et al., 2007). If on the one hand, some studies emphasize the important economic potential of the use of wheat straw as an energy source, on the other hand, environmental sus- 
tainability and in particular, the depletion of SOM (Powlson et al., 2011) must be taken into account. In fact, the off-farm use of wheat straw has to follow sustainability criteria in order to avoid soil degradation. Hence, the goal of this work is to evaluate the soil $\mathrm{C}$ steady-state and $\mathrm{C}$ input maintain in a Mediterranean wheat system and to assess the potential availability of straw residue for alternative uses while avoiding negative impacts on SOC stock.

\section{Materials and methods}

\section{Study area biomass and soil analysis}

The SOC stock dynamic in relation to Cinput was analysed in a durum wheat-based cropping system under a semiarid environment. The data from a long-term experiment (12 years) carried out in Sparacia $\left(27^{\circ} 37^{\prime} \mathrm{N}, 13^{\circ} 42^{\prime} \mathrm{E}\right.$; Sicily, Italy) were used in previousresearch to determine the soil organic carbon behaviour under typical Mediterranean climatic conditions (Novara et al., 2016). In this study, the selected cropping systems were: i) durum wheat monocropping with aboveground residues return into soil (Ws); ii) durum wheat monocropping (W) with aboveground residues moved from the soil; and iii) durum wheat with aboveground residues moved from the soil followed by bare fallow (Wfall) (2years rotation). The mean annual precipitation is $529 \mathrm{~mm}$, and the mean annual temperature $16^{\circ} \mathrm{C}$, with $21.4^{\circ} \mathrm{C}$ as maximum and $9^{\circ} \mathrm{C}$ as minimum. The annual $\mathrm{C}$ input was estimated as the sum of $\mathrm{C}$ contained in stubble, straw, root, and rhizodeposition. At maturity, for all systems, straw and stubble were manually harvested and separated. The sampling took place in two $10 \mathrm{~m}^{2}$ in the middle of each plot. After air-drying, portions of the grain, straw, and stubble were randomly selected to be oven-dried at $60^{\circ} \mathrm{C}$ until the weight stabilised for biomass weight determination. The root plantderived biomass and $\mathrm{C}$ were estimated from the straw biomass and the ratio of stubble/root (Kong et al., 2005). In this research, the average proportions of stubble to straw biomass were estimated to be $20 \%$ and the rhizodeposition-derived $\mathrm{C}$ was assumed to be equal to the root-derived C (Bolinder et al., 1999).

The total regional straw availability was calculated by multiply durum wheat harvest area in Sicily and the straw yield per hectar.

The $\mathrm{C}$ content was assumed to be $40 \%$ for all considered inputs (Johnson et al., 2006).

The cumulative $\mathrm{C}$ input (CCi) was calculated for each cropping system by summing the $\mathrm{C}$ input for all years of the experiment. After wheat was harvested soil samples were collected (0-30 $\mathrm{cm}$ depth) using a cylinder (10 $\mathrm{cm}$ diameter), air-dried, and passed through a $2-\mathrm{mm}$ sieve. To reduce the error tolerance to less th an $\pm 5 \%$, about 2 to $4 \mathrm{~kg}$ of soil (Hitz et al., 2002) was collected per sample. SOC was determined according to Walkley and Black (1934). Soil bulk density was measured with core method.

\section{Soil organic carbon steady-state determination by segmented regression}

The response between a dependent variable (SOC) and an explanatory variable (cumulative carbon input, $\mathrm{CCI}$ ) can shows more than one linear relationship at different ranges of CCI, therefore a single linear model was not adequate as well as a nonlinear model. In this case a segmented regression approach can be used to better fit the experimental data. Contemporary the breakpoint can rapresents an estimation of the SOC steady-state in realation to CCI. The unknown value of the breakpoint (Bp) was estimated at $\mathrm{CCI}=\mathrm{Bp}$ using the following model:
$\left\{\begin{array}{l}S O C_{1}=a_{1}+b_{1} C C I \text { for } C C I \leq B p \\ S O C_{2}=a_{2}+b_{2} C C I \text { for } C C I \geq B p\end{array}\right.$

where: $\mathrm{SOC}_{1}$ and $\mathrm{SOC}_{2}$ are soil organic carbon values below and above the break point (Bp) values respectively; $a$ and $b$ are the regression intercept and angular coefficient of regressions and CCI is the cumulative carbon input. In order for the regression function to be continuous at the breakpoint, the two equations for SOC need to be equal at the breakpoint (when $\mathrm{CCI}=\mathrm{Bp}$ ):

$\mathrm{a}_{1}+\mathrm{b}_{1} \mathrm{Bp}=\mathrm{a}_{2}+\mathrm{b}_{2} \mathrm{Bp}$

Solving for $\mathrm{a}_{2}$ :

$\mathrm{a}_{2}=\mathrm{a}_{1}+\mathrm{Bp}\left(\mathrm{b}_{1}-\mathrm{b}_{2}\right)$

Then by replacing $\mathrm{a}_{2}$ with the equation above, the result is a piecewise regression model that is continuous at $\mathrm{CCI}=\mathrm{Bp}$ :

$\mathrm{SOC}=\mathrm{a}_{1}+\mathrm{b}_{1} \mathrm{CCI}$ for $\mathrm{CCI} \leq \mathrm{Bp}$

$\mathrm{SOC}=\left\{\mathrm{a}_{1}+\mathrm{Bp}\left(\mathrm{b}_{1}-\mathrm{b}_{2}\right)\right\}+\mathrm{b}_{2} \mathrm{CCI}$ for $\mathrm{CCI}>\mathrm{Bp}$

Regressions parameters and regressions ANOVA were carried out both on the single regression and on the two segmented regressions using STATA software at $90 \%$ confidence interval (STATA StataCorp., College Station, TX, USA).

\section{C input maintain}

The $\mathrm{C}$ input maintain $\left(\mathrm{C}_{\mathrm{m}}\right)$, referring to the amount of $\mathrm{C}$ input from biomass residue that is needed on a soil to maintain SOC steady-state levels, was calculated using the basic equation of the AMG model (Saffih-Hdadi and Mary, 2008) (Eq. 6). The AMG model estimates SOC stock change with time, considering the annual $\mathrm{C}$ input and mineralization coefficient.

$$
\mathrm{SOC}_{\mathrm{t}}=\mathrm{SOC}_{\mathrm{s}}+\left(\mathrm{SOC}_{\mathrm{i}}-\mathrm{SOC}\right) \mathrm{e}^{-\mathrm{kt}}+\frac{\mathrm{C}_{m} \mathrm{~h}}{\mathrm{k}}\left(1-\mathrm{e}^{\mathrm{kt}}\right)
$$

where $\mathrm{SOC}_{\mathrm{t}}$ is the $\mathrm{SOC}$ at time $\mathrm{t} ; \mathrm{SOC}_{\mathrm{s}}$ is the stable fraction of the initial SOC content, $\mathrm{SOC}_{\mathrm{i}}$ is the initial content of SOC, $\mathrm{k}$ is the mineralization rate constant, $\mathrm{m}$ is the amount of Cinput, and $\mathrm{h}$ is the humification coefficient. A value of $60 \%$ was used for the stable $\mathrm{C}$ fraction, as previous studies in the same environment showed that this is the percentage of SOC which is mainly stored in the finest soil aggregate fraction $(<25 \mu \mathrm{m})$ and therefore the most recalcitrant (Barbera et al., 2012; Novara et al., 2016). The humification coefficient of durum wheat straw was assumed to be 0.15 (Marraccini et al., 2012). The k constant, which is affected by air average temperature, clay and carbonate content, was calculated according to Boiffin et al. (1986) and Bockstaller and Girardin (2003). The $C$ input maintain $\left(C_{m}\right)$ was calculated assuming the difference of SOC between two subsequent years after reaching the steady-state level was equal to 0 and solving the equation for $C_{m}$.

$$
C_{m}=\frac{\left(S O C_{i}-S O C_{s}\right) e^{-k_{t+1}}-\left(S O C_{i}-S O C_{s}\right) e^{-k_{t}}}{h\left(1-e^{-k_{t+1}}\right)-h\left(1-e^{-k_{t}}\right)} * K
$$




\section{Results and discussion}

\section{Soil carbon steady-state}

In durum wheat-based cropping system, the SOC stock is not directly correlated to CCI. The different cropping systems showed the lowest CCI in Wfall $\left(10.2 \mathrm{Mg} \mathrm{ha}^{-1}\right)$, followed by W $(17.8 \mathrm{Mg}$ $\mathrm{ha}^{-1}$ ) and Ws (48.1 $\left.\mathrm{Mg} \mathrm{ha}^{-1}\right)$. Therefore, it is needed to assess the lower CCI to maintain SOC at steady-state. Many researches have looked for critical thresholds associated with ecological studies (Andren, 1994; Fahrig, 2001). Critical thresholds occur when the responses of an ecological process are not linear, but changes sharply and suddenly (breakdown) at a determined level that can be considered the threshold level. Soil ecological processes, and in particular SOM sequestration, adheres to these basic principles, with the threshold after breakdown being considered the soil $\mathrm{C}$ steady-state level. In fact, changes in management regimes may have different threshold type effects if processes are evaluated through time.

Analysis of the segmented regression determined a breakpoint at $16.1 \mathrm{Mg} \mathrm{ha}^{-1}$ of CCI, corresponding to $37.3 \mathrm{Mg} \mathrm{ha}^{-1}$ of SOC. Regressions ANOVA showed the segmented regressions fit data better than a single regression. Less than fifty percent of total variance was explained if the single regression was applied. On the contrary, segmented regression was able to explain more than ninety percent of the total variance. Both analyses were characterized by a high significance level (Table 1).

Regression under the breakpoint showed a high SOC sequestration rate $\left(\mathrm{R}^{2}=0.96\right)$, whereas after the breakpoint the slope regression was not significantly different than $0(\mathrm{P}=0.06)$ (Figure 1 and Table 2). For this reason the constant in the $>\mathrm{Bp}$ regression can be considered the SOC steady-state level. Constant in the $<\mathrm{Bp}$ regression is the theoretical SOC stock at zero $\mathrm{C}$ input. The slope regression under the breakpoint can be used to estimate the soil $\mathrm{C}$ sequestration duration in relation to cropping system $\mathrm{C}$ input. The duration represents the ratio between $\mathrm{SOC}(\mathrm{SOC}=\mathrm{SOC}$ at $\mathrm{Bp}-$ theoretical SOC stock at zero $\mathrm{C}$ input) and annual $\mathrm{C}$ input (Figure 2). According to annual $\mathrm{C}$ input, the $\mathrm{C}$ steady-state was achieved after 3.4 years and 9 years with an annual $\mathrm{C}$ input of $4.5 \mathrm{Mg} \mathrm{ha}^{-1}$ and 1.7 $\mathrm{Mg} \mathrm{ha}^{-1}$ (corresponding to 11.3 and $4.3 \mathrm{Mg} \mathrm{ha}^{-1}$ of wheat residue), respectively. In this 12 years long term experiment, the $\mathrm{C}$ steadystate level was not reached with the annual $\mathrm{C}$ input determined by Wfall cropping system $\left(0.9 \mathrm{Mg} \mathrm{ha}^{-1}\right)$ (Figure 2, dotted line). Knowledge of time over which SOC steady-state occurs for a specific cropping system could be useful for SOC prediction and designing environmental policy based on $\mathrm{C}$ accounts.

\section{Carbon input maintain}

The $\mathrm{C}$ maintain, calculated after the breakpoint, was $3.15 \mathrm{Mg}$ $\mathrm{ha}^{-1} \mathrm{yr}^{-1}$ of wheat biomass, corresponding to $1.03 \mathrm{Mg} \mathrm{ha}^{-1} \mathrm{y}^{-1}$ of $\mathrm{C}$ input. This value represents the critical $\mathrm{C}$ input to maintain the $\mathrm{C}$ steady-state level and is affected mainly by pedoclimatic characteristics and input quality. Johnson et al. (2014), for instance, estimated that the average minimum residue return of corn stover needed to maintain SOC levels was $5.74 \pm 2.4 \mathrm{Mg} \mathrm{ha}^{-1} \mathrm{yr}^{-1}$ using a dataset from 19 field in USA. In India Srinivasarao et al. (2012) found that a minimum input of $1.13 \mathrm{Mg} \mathrm{C} \mathrm{ha} \mathrm{yr}^{-1}$ was required for sustenance of SOC levels in rainfed fingermillet.

The value of $\mathrm{C}$ maintain estimated in this work was lower than the value of $2 \mathrm{Mg} \mathrm{C} \mathrm{ha}^{-1} \mathrm{yr}^{-1}$ estimated by Wang et al. (2016) in another wheat system using the RothC model. However, the Wang et al. study reported high variability depending on soil and climatic
Table 1. ANOVA table for the linear regression without and with breakpoint. Significant regressions were considered at $P \leq 0.05$.

\begin{tabular}{lccccc} 
& SS & DF & Var & F & P \\
Without breakpoint & & & & & \\
$\quad$ Explained & 64.3 & 1 & 64.3 & 12.29 & 0.004 \\
$\quad$ Unexplained & 83.7 & 16 & 5.23 & & \\
With breakpoint & & & & & \\
$\quad$ Explained & 139.4 & 3 & 46.49 & 76.12 & 0.000 \\
$\quad$ Unexplained & 8.54 & 14 & 0.61 & & \\
\hline
\end{tabular}

Table 2. Results of regression of SOC $\left(\mathrm{Mg} \mathrm{ha}^{-1}\right)$ against $\mathrm{CCI}(\mathrm{Mg}$ $\mathrm{ha}^{-1}$ ) with optimal breakpoint (Bp).

\begin{tabular}{lcccccc} 
& Bp & d.f. & SOC & s.d. & CCI & s.d. \\
Without Bp & 8.72 & 18 & 35.5 & 2.9 & 25.4 & 1.72 \\
$\mathrm{X}<\mathrm{Bp}$ & 16.01 & 7 & 32.4 & 2.3 & 10.9 & 2.20 \\
\hline $\mathrm{X}>\mathrm{Bp}$ & 16.01 & 11 & 37.5 & 0.8 & 34.6 & 0.16 \\
\hline
\end{tabular}

$\mathrm{CCI}$, independent variable; s.d., standard deviation; d.f., freedom degree.

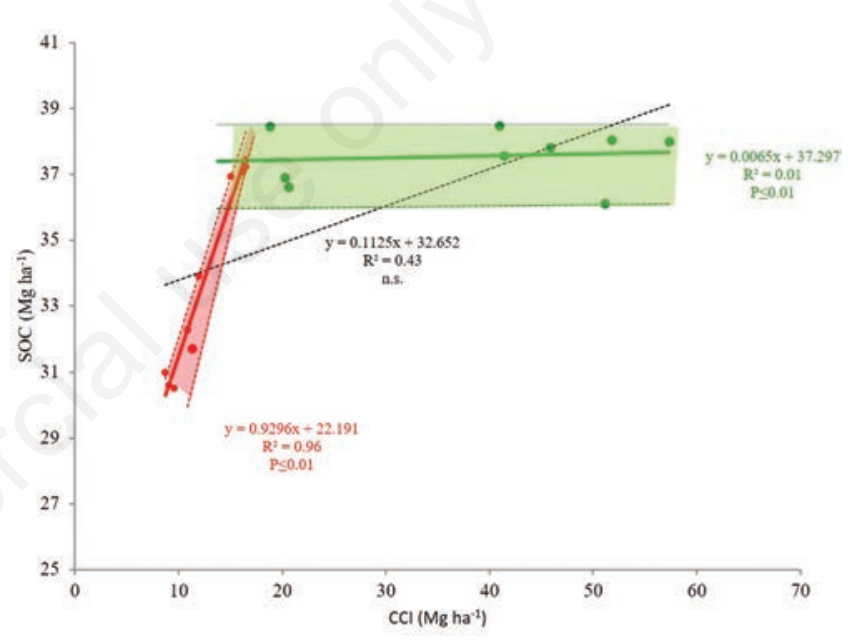

Figure 1. Regressions with (red and green line) and without (black dotted line) breakpoint. Red and green areas are confidence intervals at 10 and $\mathbf{9 0 \%}$ for the breakpoint regression.

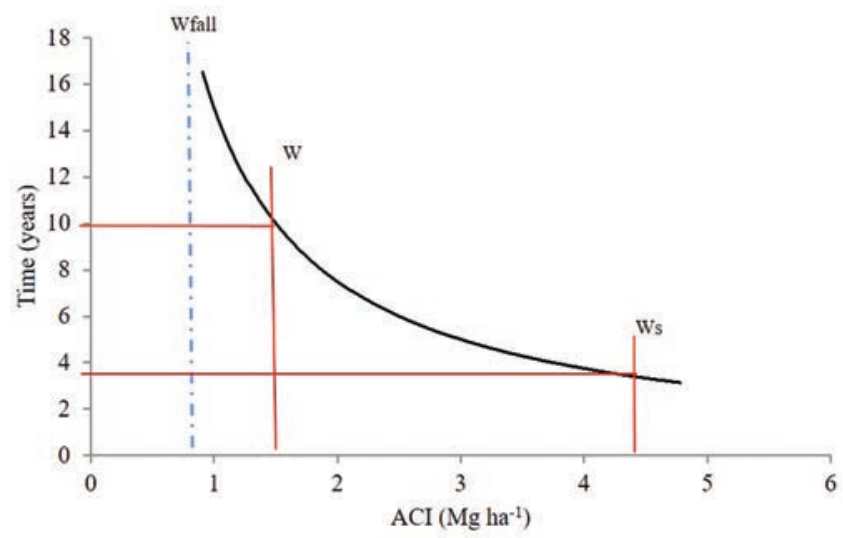

Figure 2. Annual carbon input (ACI) in relation to years needed to reach the $\mathrm{C}$ steady-state level. The dotted line represents an annual $\mathrm{C}$ input of $0.9 \mathrm{Mg} \mathrm{ha}^{-1}$, that is not enough to reach the steady-state after 12 years. Wfall, wheat-fallow cropping system; W, wheat monocropping without straw return; Ws, wheat monocropping with straw return. 
characteristics; the values were highest in the United States and Western Europe, indicating that more $\mathrm{C}$ input is needed to maintain $\mathrm{C}$ steady-state in wetter and warmer regions. Better mapping and modelling of soil properties distribution and incorporating those soil properties into models could help eliminate some of this variability. In this study the low $\mathrm{C}$ maintain value is related to the dry climatic condition and the low current soil $\mathrm{C}$ stock present in this area. Moreover, a high percentage of the soil $\mathrm{C}$ stock can be considered stable because is mineralogically protected by the high clay content of the soil fraction and therefore the potential mineralizable C pool is low (Barbera et al., 2011).

\section{Regional wheat straw assessment and potential avail- ability}

Determining an amount of straw that can be removed from soil without altering $\mathrm{C}$ stocks must take into account that the straw is important both from an ecological point of view and in economics terms, considering the increasing interest in straw for alternative uses. In Sicily, in the last seven years the durum wheat cultivated area was stable at about 290,000 ha with an average grain yield of $2.8 \pm 0.9 \mathrm{Mg} \mathrm{ha}^{-1}$ (ISTAT, 2016). Total durum wheat residue yield (straw, roots, rhizodeposition, and stubble) is estimated as $5.3 \mathrm{Mg}$ ha $^{-1}$ year $^{-1}$ (Carbon input $=2.12 \mathrm{Mg} \mathrm{ha}^{-1} \mathrm{yr}^{-1}$ ) with a total regional value of $15,472,217 \mathrm{Mg} \mathrm{yr}^{-1}$. As far as straw availability, it is estimated about 3.2 $\mathrm{Mg} \mathrm{ha}^{-1} \mathrm{yr}^{-1}$ (Carbon input $=1.28 \mathrm{Mg} \mathrm{ha}^{-1} \mathrm{yr}^{-1}$ ) and therefore there are $9,283,330 \mathrm{Mg} \mathrm{yr}^{-1}$ of total straws produced in Sicily each year.

Considering a durum wheat straw harvest efficiency of $85 \%$, an effective availability of $7,890,830 \mathrm{Mg} \mathrm{yr}^{-1}$ seems to be more realistic. Therefore, the effective $\mathrm{C}$ input $\left(1.03 \mathrm{Mg} \mathrm{C} \mathrm{ha}^{-1} \mathrm{yr}^{-1}\right)$ is determined by the contribution of roots, rhizodeposition and stubble $\left(0.84 \mathrm{Mg} \mathrm{C} \mathrm{ha}^{-1} \mathrm{yr}^{-1}\right)$ and by the $15 \%$ of straw left into the soil after harvest $\left(0.19 \mathrm{Mg} \mathrm{C} \mathrm{ha}^{-1} \mathrm{yr}^{-1}\right)$.

Because the durum wheat higher heating value (HHV) is 17.9 $\mathrm{MJ} \mathrm{kg}^{-1}$, around 141 million of $\mathrm{MJ}$ represents the regional potential energetic contribution from durum straw (Channiwala and Parikh, 2002). Although the relatively lower HHV of wheat straw in comparison to other material (i.e., the HHV of diesel oil is $45.7 \mathrm{MJ} \mathrm{kg}^{-1}$ ), the remain straw over $\mathrm{C}$ input maintain could be a valid contribution to alternative energy source to reduce petroleum consumption (Channiwala and Parikh, 2002).

Upscaling estimates for a whole region based on a long term experiment conducted over a limited geographic extent could be affected by the same uncertainties that affect the models. In fact, stocastical models used to estimate soil $\mathrm{C}$ stock show large variability due to uncertainties in climate, soils, cropping systems, etc. and a lack of long term empirical data.

\section{Conclusions}

Straw return into the soil is essential to rapidly reaching and then maintaining a SOC steady-state level in wheat systems, and therefore it should be encouraged as a recommended management practice in Mediterranean types ecosystems. Results of this study showed that a $\mathrm{C}$ steady-state can be achieved after 3.4 years with an annual $\mathrm{C}$ input of $4.5 \mathrm{Mg} \mathrm{ha}^{-1}$. Only after reaching a steadystate is possible to use the straw yield for alternative uses, because $1.03 \mathrm{Mg} \mathrm{C} \mathrm{ha}^{-1} \mathrm{yr}^{-1}$ is needed to maintain the SOC level and more than $1.03 \mathrm{Mg} \mathrm{ha}^{-1}$ are provided by roots, stubble, and rhizodeposition. Estimating the duration to reaching SOC steady-state is affected by climatic and pedological uncertains, that should deeply investigated for a more reliable evaluation of the ecological contribution of the proposed wheat straw management at regional level.

\section{References}

Andren H, 1994. Effects of habitat fragmentation on birds and mammals in landscapes with different proportions of suitable habitat: a review. Oikos 71:355-66.

Antoni D, Zverlov VV, Schwarz WH, 2007. Biofuels from microbes. Appl. Microbiol. Biotechnol. 77:23-35.

Barbera V, Poma I, Gristina L, Novara A, Egli M, 2012. Long-term cropping systems and tillage management effects on soil organic carbon stock and steady state level of $\mathrm{C}$ sequestration rates in a semiarid environment. Land Degrad. Develop. 23:82-91.

Bleuler M, Farina R, Francaviglia R, di Bene C, Napoli R, Marchetti A, 2017. Modelling the impacts of different carbon sources on the soil organic carbon stock and $\mathrm{CO}_{2}$ emissions in the Foggia province (Southern Italy). Agricult. Syst. 157:25868.

Bockstaller C, Girardin P, 2003. How to validate environmental indicators. Agricult. Syst. 76:639-53.

Boiffin J, KéliZagbahi J, Sebillotte M, 1986. Systèmes de culture et statutorganique des sols dans le Noyonnais: application du modèle de Hénin-Dupuis. Agronomie 6:437-47.

Bolinder MA, Angers DA, Giroux M, Laverdiere MR, 1999. Estimating $\mathrm{C}$ inputs retained as soil organic matter from corn (Zea mays L.). Plant Soil 215:85-91.

Cerdà A, González-Pelayo $\mathrm{O}$, Giménez-Morera A, Jordán A, Pereira P, Novara A, Brevik, EC, Prosdocimi M, Mahmoodabadi M, Keesstra S, García Orenes F, Ritsema C, 2016. The use of barley straw residues to avoid high erosion and runoff rates on persimmon plantations in Eastern Spain under low frequency - high magnitude simulated rainfall events. Soil Res. 54:154-65.

Channiwala SA, Parikh PP, 2002. A unified correlation for estimating HHV of solid, liquid and gaseous fuels. Fuel 81:1051-63.

Chen X, Duan Z, Tan M, 2016. Restoration affect soil organic carbon and nutrients in different particle-size fractions. Land Degrad. Develop. 27:561-72.

de Moraes Sá JC, Séguy L, TivetF, Lal R, Bouzinac S, Borszowskei PR, Briedis C, Bürkner dos Santos J, Da Cruz Hartman D, Bertoloni CG, Rosa J, Friedrich T, 2015. Carbon depletion by plowing and its restoration by no-till cropping systems in oxisols of subtropical and tropical agro-ecoregions in Brazil. Land Degrad. Develop. 26:531-43.

Dikgwatlhe SB, Chen ZD, Lal R, Zhang HL, Chen F, 2014. Changes in soil organic carbon and nitrogen as affected by tillage and residue management under wheat-maize cropping system in the North China Plain. Soil Till. Res. 144:110-8.

Fahrig L, 2001. How much habitat is enough? Biol. Conserv. 100:65-74.

Farina R, Marchetti A, Francaviglia R, Napoli R, Di Bene C, 2017. Modeling regional soil $\mathrm{C}$ stocks and $\mathrm{CO} 2$ emissions under Mediterranean cropping systems and soil types. Agricult. Ecosyst. Environ. 238:128-41.

García-Díaz A, Allas RB, Gristina L, Pereira P, Novara A, 2016. Carbon input threshold for soil carbon budget optimization in eroding vineyards. Geoderma 271:144-9.

Gray KA, Zhao L, Emptage M, 2006. Bioethanol. Curr. Opin. Chem. Biol. 10:141-6. 
ISTAT, 2016. ISTAT database. Available at: http://agri.istat.it Johnson JMF, Allmaras RR, Reicosky DC, 2006. Estimating Source Carbon from Crop Residues, Roots and Rhizodeposits Using the National Grain-Yield Database. Agron. J. 98:622-36.

Johnson JMF, Novak JM, Varvel GE, Stott DE, Osborne SL, Karlen DL, Lamb JA, Baker J, Adler PR, 2014. Crop residue mass needed to maintain soil organic carbon levels: can it be determined? BioEner. Res. 7:481-90.

Hitz C, Egli M, Fitze P. 2002. Determination of the sampling volume forrepresentative analysis of alpine soils. Zeitschr. Pflanzenernähr. Bodenk. 165:326-31.

Kong AYY, Six J, Bryant DC, Denison RF, van Kessel C, 2005. The relationship between carbon input, aggregation, and soil organic carbon stabilization in sustainable cropping systems. Soil Sci. Soc. Am. J. 69:1078-85.

Lafond GP, Stumbor M, Lemke R, May WE, Holzapfel CB, Campbell CA, 2009. Quantifying straw removal through baling and measuring the long-term impact on soil quality and wheat production. Agron. J. 101:529-37.

Lal R, 2005. World crop residues production and implications of its use as a biofuel. Environ. Int. 31:575-84.

Liu C, Lu M, Cui J, Li B, Fang C, 2014. Effects of straw carbon input on carbon dynamics in agricultural soils: a meta-analysis. Global Change Biol. 20:1366-81.

Marraccini E, Debolini M, Di Bene C, Rapey H, Bonari E, 2012. Factors affecting soil organic matter conservation in Mediterranean hillside winter cereals-legumes cropping systems. Ital. J. Agron. 3:283-92.

Novara A, Poma I, Sarno M, Venezia G, Gristina L, 2016. Long term durum wheat-based cropping systems result in the rapid saturation of soil carbon in the Mediterranean semiarid environment. Land Degrad. Develop. 27:612-9.

Powlson DS, Glendining MJ, Coleman K, Whitmore AP, 2011. Implications for soil properties of removing cereal straw: results from long-term studies. Agron. J. 103:279-87.

Qureshi N, Saha BC, Dien B, Hector RE, Cotta MA, 2010. Production of butanol (a biofuel) from agricultural residues: Part I - Use of barley straw hydrolysate. Biomass Bioener. 34:559-65.

Saffih-Hdadi, K, Mary B, 2008. Modeling consequences of straw residues export on soil organic carbon. Soil Biol. Biochem. 40:594-607.

Samahadthai P, Vityakon P, Saenjan P, 2010. Effects of different quality plant residues on soil carbon accumulation and aggregate formation in a tropical sandy soil in Northeast Thailand as revealed by a 10-year field experiment. Land degradation and development 21:463-73.

Scarlat N, Martinov M, Dallemand JF, 2010. Assessment of the availability of agricultural crop residues in the European Union: potential and limitations for bioenergy use. Waste Manage. 30:1889-97.

Smith P, Cotrufo MF, Rumpel C, Paustian K, Kuikman PJ, Elliott JA, McDowell R, Griffiths RI, Asakawa S, Bustamante M, House JI, Sobocká J, Harper R, Pan G, West PC, Gerber JS, Clark JM, Adhya T, Scholes RJ, Scholes MC, 2015. Biogeochemical cycles and biodiversity as key drivers of ecosystem services provided by soils. Soil 1:665-85.

Srinivasarao Ch, Venkateswarlu B, Singh AK, Vittal KPR, Kundu S, Gajanan GN, Ramachandrappa B, Chary GR, 2012. Critical carbon inputs to maintain soil organic carbon stocks under long term finger millet (Eleusinecoracana (L.) Gaertn) cropping on Alfisols in semi arid tropical India. J. Plant Nutr. Soil Sci. 175:681-8.

Walkley A, Black IA, 1934. An examination of the Degtjareff method for determining soil organic matter and a proposed modification of the chromic acid titration method. J. Soil Sci. 37:29-38.

Wamukonya L, Jenkins B, 1995. Durability and relaxation of sawdust and wheat-straw briquettes as possible fuels for Kenya. Biomass Bioener. 8:175-9.

Wang G, Luo Z, Han P, Chen H, Xu J, 2016. Critical carbon input to maintain current soil organic carbon stocks in global wheat systems. Sci. Report 6 [Epub ahead of print].

Wilhelm WW, Johnson JMF, Hatfield JL, Voorhees WB, Linden DR, 2004. Crop and soil productivity response to corn residue removal: a literature review. Agron. J. 96:1-17.

Xia L, Wang S, Yan X, 2014. Effects of long-term straw incorporation on the net global warming potential and the net economic benefit in a rice-wheat cropping system in China. Agric. Ecosyst. Environ. 197:118-27. 